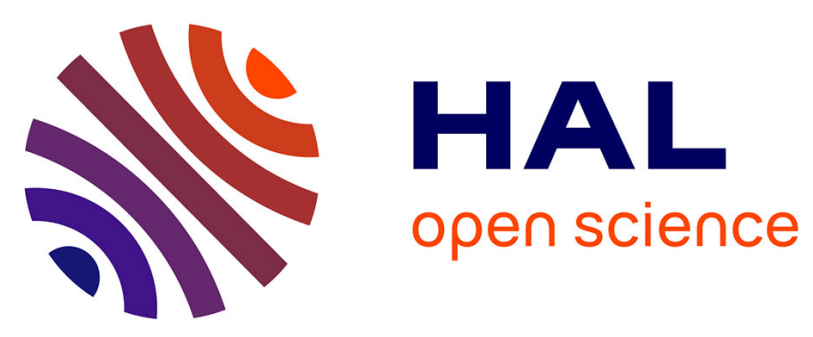

\title{
Unfavourable pattern of metastases in M0 breast cancer patients during 1978-2008: a population-based analysis of the Munich Cancer Registry
}

Corina J. G. Hurk, Renate Eckel, Lonneke V. Poll-Franse, Jan Willem W. Coebergh, Johan W. R. Nortier, Dieter Hölzel, Wim P. M. Breed, Jutta Engel

\section{To cite this version:}

Corina J. G. Hurk, Renate Eckel, Lonneke V. Poll-Franse, Jan Willem W. Coebergh, Johan W. R. Nortier, et al.. Unfavourable pattern of metastases in M0 breast cancer patients during 1978-2008: a population-based analysis of the Munich Cancer Registry. Breast Cancer Research and Treatment, 2011, 128 (3), pp.795-805. 10.1007/s10549-011-1372-y . hal-00615400

\author{
HAL Id: hal-00615400 \\ https://hal.science/hal-00615400
}

Submitted on 19 Aug 2011

HAL is a multi-disciplinary open access archive for the deposit and dissemination of scientific research documents, whether they are published or not. The documents may come from teaching and research institutions in France or abroad, or from public or private research centers.
L'archive ouverte pluridisciplinaire HAL, est destinée au dépôt et à la diffusion de documents scientifiques de niveau recherche, publiés ou non, émanant des établissements d'enseignement et de recherche français ou étrangers, des laboratoires publics ou privés. 
Unfavourable pattern of metastases in M0 breast cancer patients during 19782008: a population based analysis of the Munich Cancer Registry

Corina J.G. van den Hurk' ${ }^{1,2}$, Renate Eckel ${ }^{3}$, Lonneke V. van de Poll-Franse ${ }^{2,4}$, Jan Willem W.

Coebergh $^{2,5}$, Johan W.R. Nortier ${ }^{1}$, Dieter Holzel $^{3}$, Wim P.M. Breed ${ }^{2}$, Jutta Engel ${ }^{3}$

${ }^{1}$ Leiden University Medical Center, Department of Clinical Oncology, PO Box 9600, 2300 RC Leiden, The Netherlands

${ }^{2}$ Comprehensive Cancer Center South, PO Box 231, 5600 AE Eindhoven, The Netherlands

${ }^{3}$ Munich Cancer Registry of the Munich Cancer Center, Department of Medical Informatics,

Biometry and Epidemiology, Ludwig-Maximilians University, Marchioninistraße 15,

81377 Munich, Germany;

${ }^{4}$ CoRPS - Center of Research on Psychology in Somatic diseases, Tilburg University, PO Box 90153, 5000 LE Tilburg, The Netherlands

${ }^{5}$ Department of Public Health, Erasmus University Medical Center, PO Box 2040, 3000 CA

Rotterdam, The Netherlands

\section{Address for correspondence:}

Corina van den Hurk, Comprehensive Cancer Center South (IKZ), PO Box 231, 5600 AE

Eindhoven, The Netherlands, Tel.: +31 40 2971616; Fax: +31 40 2971610; E-mail:

c.vd.hurk@ikz.nl and research@ikz.nl

Key words: metastases pattern, time to metastases, survival, breast cancer 


\section{ABSTRACT}

\section{Purpose}

Little is known about time trends in metastases in patients treated in routine health care facilities without metastases at diagnosis (M0) and about survival after these metastases.

\section{Methods}

Data on 33,771 M0 patients with primary breast cancer diagnosed between 1978 and 2003 were obtained from the Munich Cancer Registry. Survival analyses were restricted to patients with metastases within 5 years of the initial diagnosis.

\section{Results}

The incident number of patients approximately doubled each period and 5-year overall survival increased from $77 \%$ in the first to $82 \%$ percent in the last period. $5490(16 \%)$ M0 patients developed metastases within 5 years after the initial diagnosis. The hazard of developing metastases was lowest in the most recent period compared to the first period $(H R=0.50$, $p<0.001)$. The hazard of dying after metastases was equal for patients diagnosed between 1978 to 1984 and 1995 to 2003 (HR 1.08, p=0.3). The percentage of patients that developed bone metastases decreased each time period, but the percentages primary liver and CNS metastases increased. Exclusion of site of metastases in the multivariate analysis led to a $20 \%(p=0.02)$ higher hazard of dying following metastases in the last versus the first period.

\section{Conclusions}

In the period 1978-2008, unfavourable changes in the pattern of metastases were exhibited and no improvement was observed in survival of patients after occurrence of metastases. An explanation might be the increased use of adjuvant systemic treatment, which has less effect on the highly lethal liver and CNS metastases than on bone metastases. The increased use also appeared to contribute to the overall prevention of metastases in breast cancer and therefore to improvement of overall survival. 


\section{INTRODUCTION}

The prevalence of breast cancer patients without metastases at diagnosis (M0) has increased in industrialised countries. This increase can be explained by the rising incidence and decreasing overall mortality rate of breast cancer[1-4], which is attributed to earlier detection and therefore advantageous stage distribution, and improvements in treatment.[1] The early detection is largely due to breast cancer screening, developments in imaging and higher awareness of the disease among women. One would expect that these developments would influence the occurrence of metastases at diagnosis and in follow-up.

The reported percentage of M0 patients with metastases in follow-up is $20 \%$ to $30 \%$.[3] The proportion of patients with metastases at initial diagnosis (M1) remains stable at about $5 \%[1,5]$ or decreases minimally.[6] In M1 patients, patterns of metastases and survival are frequently described, but the progression patterns and time trends of occurrence of metastases after initial treatment in M0 patients are seldom investigated. The objective of this study was to describe the incidence of metastases and survival after metastases in M0 breast cancer patients since 1978. Therefore, this study will provide knowledge about the level of progress in medical management of metastases in these patients. Data were obtained from the Munich Cancer Registry (MCR), which uniquely documents metastases during followup.[7]

\section{PATIENTS AND METHODS}

\section{Study population and data collection}

Data on breast cancer patients diagnosed in the period 1978-1984, 1985-1994 and 1995-2003 were obtained from the population-based MCR. The MCR has in the last period a catchment area of 2.5 million residents (since 20023.9 million residents) and records data on all patients newly diagnosed with cancer.[8, 9] The unequal subdivision into time periods of initial diagnosis marks steps in the changes from a hospital-based (up to 1984) to a populationbased registry of Munich and surrounding area's. The MCR is for breast cancer population- 
based since 1994, when the pathologists of the region started structural cooperation with the MCR. Data on primary diagnosis and progression were provided by the hospitals in the Munich region by means of tumour-specific reporting forms, doctors' letters and pathology reports and nowadays also through online documentation. Diagnosis of metastases was based on radiological imaging, physical evaluation or histological examination in regular oncological follow-up. Life status information was obtained from the population registration offices and death certificates until October $1^{\text {st }} 2007$ and is complete for more than $90 \%$ of patients.[7] In the Munich catchment area screening for breast cancer has increased over time since the beginning of the 1990s, was initially opportunistic and at the end widespread, before programmed screening was started in 2004.

Between 1978 and 2003, the MCR registered 36,002 female patients diagnosed with primary invasive breast cancer. The data set did not include patients with secondary malignancies or sarcomas or with only a death certificate. Follow-up was complete up to October 30, 2008.

\section{Statistical analysis}

Statistical analyses included time to metastases within 5 years of initial diagnosis and survival following the first metastasis among patients who developed a metastasis within 5 years of initial diagnosis. Metastases were included in the analyses grouped by the most frequent sites of occurrence or combinations of these specific sites. These combinations were independent of sequence of metastatic sites and synchronous or metachronous detection and were only inserted if no additional metastases were present at rarer sites. Loco regional skin or lymph node recurrences were excluded. Event-free patients were censored on October 302008 and patients who were lost to follow-up at their last date of contact. Survival times, time to metastases and survival after metastases were described with the Life-Table method and tested with the log-rank test. For determining the importance of the independent variables Cox proportional hazards regression models were used, in which missing values were recoded into 
dummy variables. The enclosed variables were: period of diagnosis, age, tumour size (pT), lymph node status $(\mathrm{pN})$, grade, receptor status and histological type. Analyses regarding time to metastases also included resection margins, initial radiotherapy and systemic therapy. Additional variables for survival following metastases were time to metastases and site(s) of metastases. When evaluating the proportional hazard assumption of the main objective of this study, namely period of diagnosis, the graphs of the survival function versus the survival time yielded parallel curves as did the graphs of the $\log (-\log ($ survival $))$ versus log of survival time.

The SAS computer package (version 9.1) was used for all statistical analyses (SAS Institute Inc., Cary, NC, USA, 1999).

\section{RESULTS}

\section{General characteristics of MO patients}

The MCR comprised 33,771 M0 patients and 2231 (6\%) M1 patients who were diagnosed with breast cancer between 1978 and 2003. For M0 patients, median follow-up time for patients alive or lost to follow-up ranged from 177 months in the period 1985-1994 (50\% of patients were deceased on Oct. $1^{\text {st }} 2008$ ) to 80 months in $1995-2003$ (25\% of patients were deceased on Oct. $1^{\text {st }}$ 2008) (Table 1). The incident number of patients approximately doubled each period and during follow-up 8183 (24\%) patients developed a metastasis after M0 at diagnosis, $5490(67 \%)$ of whom within 5 years of initial diagnosis. An increase in 5-year overall survival was observed for the last period (77\% vs. $76 \%$ vs. $82 \%, p<0.0001)$ (Figure 1).

In time, the observed proportion of patients diagnosed with pT1 and lymph nodenegative tumours increased, as did the proportion of older women (70+) (Table 1). About $80 \%$ of patients had a tumour of the ductal type and positive ostrogen (ER) or progesteron (PR) receptors. Unknown receptor status decreased considerably from the second (46\%) to the third study period (16\%), while the ratio of positive to negative receptors hardly changed. The proportion of patients who underwent mastectomy decreased from $98 \%$ in the first to $35 \%$ in the last period and systemic treatment was used more often in recent periods (22\% vs. $44 \%$ 
vs. $70 \%$ ). A decrease in the proportion of patients undergoing radiotherapy was seen in period 1985-1994.

\section{Patterns of metastases}

In the cohort of $5490 \mathrm{M0}$ patients with metastases within 5 years of initial diagnosis, $59 \%$ developed the first metastasis within 2.5 years (Table 2 ). Overall $56 \%$ of the patients developed metastases at 2 or more sites and the proportion of metachronously diagnosed metastases increased in time from $66 \%$ to $82 \%$. The proportion of bone metastases declined (69\% vs. $62 \%$ vs. $47 \%$ ) while the proportion of liver, central nervous system (CNS) and less common occurring sites of metastases increased. In time, trends were comparable for the first detected metastases. In the first period $85 \%$ of patients died within 5 years of the first metastases versus $95 \%$ in the last period. Of patients alive or lost to follow-up, median followup was 29 months in the first period, 11 months in 1985 to1994 and 50 months in 1995-2003. Patients who developed metastases within 5 years had a positive lymph node status at initial diagnosis more often and had a higher $\mathrm{pT}$ status than M0 patients in general.

\section{Time from diagnosis to first metastasis}

The proportion M0 patients who developed metastases within 5 years of initial diagnosis declined significantly from $27 \%$ in $1978-1984$ to $15 \%$ in $1995-2003$ ( $p<0.0001$ ) (Figure 2a). Overall, the risk of occurrence of metastases was highest in the first 2.5 years of initial diagnosis (65\% vs. $60 \%$ vs. $56 \%$ ), as also indicated by the steepness of the curves in Figure

3. For the specified metastatic sites, only small differences emerged in time to detection during 5 years of follow-up, except for skin metastases that appeared later. Detection of metastases occurred within 5 years of initial diagnosis in $76 \%$ of patients who developed a combination of bone, liver and lung metastases and in $52 \%$ of patients with skin metastases only.

The hazard of developing metastases within 5 years of diagnosis was lowest in the most recent period $(\mathrm{HR}=0.50, \mathrm{p}<0.001)$ (Table 3). A positive receptor status $(\mathrm{HR}=0.61$, 
$\mathrm{p}<0.001)$ and the combination of chemotherapy and hormonal therapy $(H R=0.69, p<0.001)$ were associated with a lower risk of metastases. Age and radiotherapy were not significantly associated with the occurrence of metastases within 5 years.

\section{Time from first metastasis to death}

If only the death certificate or a post mortem report indicated metastases, the date of first metastasis was similar to the date of death and these patients were excluded from survival analyses $(n=6251)$.

In M0 patients with metastases within 5 years of initial diagnosis, 5-year actuarial survival rates after occurrence of first metastasis decreased and differed significantly between the time periods ( $17 \%$ vs. $12 \%$ vs. $8 \%, p=0.0001$ ) (Figure $2 b$ ).

Multivariate regression analysis showed that patients who developed a metastasis within 5 years of diagnosis in the period 1985-1994 had a 20\% increased hazard of dying compared to those in 1978-1984 and 1995-2003; this first and last period showed no difference in survival (Table 4). However, when site of metastases was removed from the model, then the hazard ratios became $1.24(p=0.003)$ and $1.21(p=0.02)$ for the last two periods. Mortality risk increased with the increase in age and a higher $\mathrm{pT}$, positive lymph nodes and differentiation grade. The hazard of dying for patients with metastases was 35\% lower for receptor status-positive patients and decreased $7 \%$ in each additional year between initial diagnosis and first metastasis.

Prognosis for patients after metastases varied for the site(s) of metastasis (Table 3). Up to 5 years after detection of metastases, patients with bone metastases or skin metastases alone exhibited best survival (Figure 5). From 5 to 10 years, skin alone and distant lymph node alone had best prognosis up to 10 years after detection of metastases (data not shown).

\section{DISCUSSION}


In the period 1978-2008, the hazard of developing metastases during follow-up decreased markedly and overall survival improved among women diagnosed with M0 breast cancer. Concurrently, we observed a change in the anatomic pattern of metastasis, without improvement in survival after occurrence of these metastases. There might be several explanations for our observations.

We attribute the generally improved survival of $\mathrm{MO}$ patients in the last period to adjuvant, especially hormonal, treatment which was routinely administered at that time. In addition, patients recorded by the MCR showed advantageous stage distribution over the periods, which also contributed to improved prognosis. Time from initial diagnosis to metastasis is prolonged for $\mathrm{pT} 1$ versus $\mathrm{pT} 2[8]$, but changes in adjuvant systemic treatment will also have lengthened the time.[10,11] The adjuvant treatment prevents the development of metastases or at least postpones it. However, if dormant tumour cells start growing again, whether due to resistance against the continued systemic therapy or not, then the survival time of the metastasized patients remained as poor as before. Over time, the proportional anatomic distribution of metastasis shifted from bone, with long survival times, towards CNS and liver, which are much more lethal. This shift has also been reported by others, but only for the first site of metastasis.[12] The increased use of hormonal treatment might cause the shift since ER-positive tumours tend to metastasize to bone, ER and PR negativity are commonly associated with visceral metastases, especially liver and CNS.[13-18] The increased proportion of CNS metastases might also reflect improvement in adjuvant systemic treatment; CNS is regarded as a sanctuary site, that is less affected by most therapeutics than other sites.[19] In this study liver metastases, alone or in combination, occurred earliest during follow-up and were like CNS metastases, the most lethal. So, the largest benefit in the survival of patients with breast cancer will most likely come from the prevention and better treatment of CNS and liver metastases. In patients with over expression of HER2 major improvements have been reached with trastuzumab[20] and recently lapatinib.[21, 22] Bisphosphonates of the third generation seem to have also an anti-tumour effect in the adjuvant setting.[23] In addition poly(adenosine diphosphate [ADP]-ribose) polymerase (PARP) inhibitors are likely to 
be beneficial for patients with triple negative tumours.[24] Therefore, the incidence and pattern of metastases will change further in the future. Overall, sites of metastases appeared to contribute largely to the period effect, since exclusion of site of metastases in the multivariate analysis increased the mortality hazard ratio for the last versus the first period to $21 \%$. Unfortunately, no information was available about the type of treatment of the metastasized cancer in the MCR region.

The worse outcome after occurrence of metastases in patients without metastasis at diagnosis might be related to less sensitive tumour cells that developed resistance after adjuvant systemic therapy. This is supported by recent observations of M1 patients who, in particular when the primary tumour had been removed completely, had a more favourable prognosis compared to M0 patients with subsequent metastases.[13, 25, 26, 27, 28] However, contradictory results have been reported of M1 patients, who sometimes had worse survival compared to M0 patients who developed metastases in follow-up.[29-32]

Higher incidence of more aggressively growing tumours might be an additional explanation of the unimproved survival after metastases, since the increasing use of breast cancer screening mainly eliminates the slowly growing tumours. This is also reflected by the highly significant relationship between time to first metastasis and survival after occurrence of metastases, which remained after correction for period of diagnosis and site(s) of metastases. More aggressive growth might also be partly attributed to the lack of effective therapies for aggressive subtypes of breast cancer, such as triple-negative, non-basal and basal-like subtypes.[33] These subtypes are known to influence the growth rate, site of metastases, time to occurrence and survival after metastases.[12, 34] In this study the majority of metastases became manifest within 2.5 years of initial diagnosis, as observed by others.[11, 13, 35, 36]

The MCR hosts unique data on clinically evident metastases in follow-up, but the prevalence of metastases in the MCR is slightly underdocumented. Surgically treated and histopathologically confirmed metastases are obtained from pathology reports and are therefore nearly complete. However, not histopathologically confirmed metastases will be documented in about $70 \%$ of cases, based on estimations of tumour-specific survival and 
relative survival, that should equalize the proportion of metastases.[7, 37] Some of the metastases are likely to remain unreported by physicians to the MCR and some might never be detected because there were no clinical manifestations before death. The MCR's completeness is difficult to check with literature, while proportions of metastatic sites in breast cancer vary considerably, both within clinical and within autopsy studies.[18, 26, 38-43] Only a few studies were population-based, and the subdivision of metastatic sites and follow-up times differed. The most adequate comparisons should be based on patients with breast cancer as the cause of death. It is likely that for the period 1995-2003, data on metastases in the MCR were more complete and most representative, while at that time the database became approximately population-based. In time, methods of detection have improved and indications for diagnostics have changed, as exhibited by the decreased proportion of missing data on pT, $\mathrm{pN}$ and receptor status. In addition, the last period showed an increased number of metastases per patient, as well as increased detection of metastases at rarer sites.

Nevertheless, the observed change in pattern of metastases can be considered to be a mirror for general specialised care in a variety of hospitals, while there were no systematic or specific diagnostics for metastases in the MCR region.

In conclusion, the enhanced use and extensive developments in systemic treatment of patients with breast cancer might have prevented development of metastases in breast cancer. It changed the anatomic distribution of sites of metastases, but did not improve survival after occurrence of metastases. The most important reason seems to be the shift from bone metastases towards CNS and liver metastases. Furthermore, there might have been a natural selection of more aggressively growing tumours in the recent period. So, at the time metastases became manifest, treatment possibilities remained insufficient, at least up to 2008 . It seems that therapies for liver and CNS metastases might yield the largest gains in survival of $\mathrm{MO}$ breast cancer patients. And lastly, changes in patterns of metastases as a result of new treatments, illustrate the importance of including registration of metastases and secondary treatment in cancer registries. They can be used to study long term effects in the population and the usefulness of new treatment strategies. 
All authors declared no conflicts of interest.

\section{REFERENCES}

1. Louwman WJ, Voogd AC, van Dijck JA, Nieuwenhuijzen GA, Ribot J, Pruijt JF, Coebergh JW: On the rising trends of incidence and prognosis for breast cancer patients diagnosed 1975-2004: a long-term population-based study in southeastern Netherlands. Cancer Causes Control 2008, 19(1):97-106.

2. Jatoi I, Chen BE, Anderson WF, Rosenberg PS: Breast cancer mortality trends in the United States according to estrogen receptor status and age at diagnosis. J Clin Oncol 2007, 25(13):1683-1690.

3. Early Breast Cancer Trialists' Collaborative Group: Effects of chemotherapy and hormonal therapy for early breast cancer on recurrence and 15-year survival: an overview of the randomised trials. Lancet 2005, 365(9472):1687-1717.

4. Gondos A, Bray F, Brewster DH, Coebergh JW, Hakulinen T, Janssen-Heijnen ML, Kurtinaitis J, Brenner H: Recent trends in cancer survival across Europe between 2000 and 2004: A model-based period analysis from 12 cancer registries. Eur J Cancer 2008, 44(10):1463-1475.

5. Edwards MJ, Gamel JW, Feuer EJ: Improvement in the prognosis of breast cancer from 1965 to 1984. J Clin Oncol 1998, 16(3):1030-1035.

6. Jensen AR, Madsen AH, Overgaard J: Trends in breast cancer during three decades in Denmark: stage at diagnosis, surgical management and survival. Acta oncologica (Stockholm, Sweden) 2008, 47(4):537-544.

7. Schlesinger-Raab A, Treiber U, Zaak D, Holzel D, Engel J: Metastatic renal cell carcinoma: results of a population-based study with 25 years follow-up. Eur J Cancer 2008, 44(16):2485-2495.

8. Engel J, Eckel R, Kerr J, Schmidt M, Furstenberger G, Richter R, Sauer H, Senn HJ, Holzel D: The process of metastasisation for breast cancer. Eur J Cancer 2003, 39(12):1794-1806.

9. Curado MP, Edwards BS, H.R., Ferlay J, Heanue M, Boyle P, Storm H: Cancer Incidence in Five Continents, Volume IX. Lyon: IARC; 2009.

10. Johansson P, Fohlin H, Arnesson LG, Dufmats M, Nordenskjold K, Nordenskjold B, Stal O: Improved survival for women with stage I breast cancer in south-east Sweden: a comparison between two time periods before and after increased use of adjuvant systemic therapy. Acta oncologica (Stockholm, Sweden) 2009, 48(4):504-513.

11. Toi M, Yamashiro H, Tsuji W: Risk reduction of distant metastasis in hormonesensitive postmenopausal breast cancer. Breast cancer (Tokyo, Japan) 2009, 16(3):207218.

12. Yerushalmi R, Woods R, Kennecke H, Speers C, Knowling M, Gelmon K: Patterns of relapse in breast cancer: changes over time. Breast cancer research and treatment 2010, 120(3):753-759.

13. Coleman RE, Smith P, Rubens RD: Clinical course and prognostic factors following bone recurrence from breast cancer. British journal of cancer 1998, 77(2):336-340.

14. Blanco G, Holli K, Heikkinen M, Kallioniemi OP, Taskinen P: Prognostic factors in recurrent breast cancer: relationships to site of recurrence, disease-free interval, female 
sex steroid receptors, ploidy and histological malignancy grading. British journal of cancer 1990, 62(1):142-146.

15. Solomayer EF, Diel IJ, Meyberg GC, Gollan C, Bastert G: Metastatic breast cancer: clinical course, prognosis and therapy related to the first site of metastasis. Breast cancer research and treatment 2000, 59(3):271-278.

16. Pestalozzi BC, Zahrieh D, Price KN, Holmberg SB, Lindtner J, Collins J, Crivellari D, Fey MF, Murray E, Pagani O et al: Identifying breast cancer patients at risk for Central Nervous System (CNS) metastases in trials of the International Breast Cancer Study Group (IBCSG). Ann Oncol 2006, 17(6):935-944.

17. Smid M, Wang Y, Klijn JG, Sieuwerts AM, Zhang Y, Atkins D, Martens JW, Foekens JA: Genes associated with breast cancer metastatic to bone. J Clin Oncol 2006, 24(15):2261-2267.

18. Kamby C: The pattern of metastases in human breast cancer: methodological aspects and influence of prognostic factors. Cancer Treat Rev 1990, 17(1):37-61.

19. Duchnowska R, Szczylik C: Central nervous system metastases in breast cancer patients administered trastuzumab. Cancer Treat Rev 2005, 31(4):312-318.

20. Mannocci A, De Feo E, de Waure C, Specchia ML, Gualano MR, Barone C, Ricciardi W, La Torre G: Use of trastuzumab in HER2-positive metastatic breast cancer beyond disease progression: a systematic review of published studies. Tumori 2010, 96(3):385391.

21. Curran MP: Lapatinib: in postmenopausal women with hormone receptor-positive, HER2-positive metastatic breast cancer. Drugs 2010, 70(11):1411-1422.

22. Arslan C, Dizdar O, Altundag K: Systemic treatment in breast-cancer patients with brain metastasis. Expert opinion on pharmacotherapy 2010, 11(7):1089-1100.

23. Reeder JG, Brufsky AM: The role of bisphosphonates in the adju vant setting for breast cancer. Oncology (Williston Park, NY 2010, 24(6):462-467, 475.

24. Underhill C, Toulmonde M, Bonnefoi H: A review of PARP inhibitors: from bench to bedside. Ann Oncol 2010.

25. Engel J, Eckel R, Aydemir U, Aydemir S, Kerr J, Schlesinger-Raab A, Dirschedl P, Holzel D: Determinants and prognoses of locoregional and distant progression in breast cancer. Int J Radiat Oncol Biol Phys 2003, 55(5):1186-1195.

26. Jimeno A, Amador ML, Gonzalez-Cortijo L, Tornamira MV, Ropero S, Valentin V, Hornedo J, Cortes-Funes H, Colomer R: Initially metastatic breast carcinoma has a distinct disease pattern but an equivalent outcome compared with recurrent metastatic breast carcinoma. Cancer 2004, 100(9):1833-1842.

27. Rapiti E, Verkooijen HM, Vlastos G, Fioretta G, Neyroud-Caspar I, Sappino AP, Chappuis PO, Bouchardy C: Complete excision of primary breast tumor improves survival of patients with metastatic breast cancer at diagnosis. J Clin Oncol 2006, 24(18):2743-2749.

28. Schlesinger-Raab A, Eckel R, Engel J, Sauer H, Lohrs U, Molls M, Holzel D: Metastasiertes Mammakarzinom: Keine Lebensverlangerung seit 20 Jahren. Deutsches Arzteblatt 2005, 102(40):A2706-A2714.

29. Andre F, Slimane K, Bachelot T, Dunant A, Namer M, Barrelier A, Kabbaj O, Spano JP, Marsiglia H, Rouzier R et al: Breast cancer with synchronous metastases: trends in survival during a 14-year period. J Clin Oncol 2004, 22(16):3302-3308.

30. Smigal C, Jemal A, Ward E, Cokkinides V, Smith R, Howe HL, Thun M: Trends in breast cancer by race and ethnicity: update 2006. CA Cancer J Clin 2006, 56(3):168183.

31. Wilcken N, Dear R: Chemotherapy in metastatic breast cancer: A summary of all randomised trials reported 2000-2007. Eur J Cancer 2008, 44(15):2218-2225. 
32. Ernst MF, van de Poll-Franse LV, Roukema JA, Coebergh JW, van Gestel CM, Vreugdenhil G, Louwman MJ, Voogd AC: Trends in the prognosis of patients with primary metastatic breast cancer diagnosed between 1975 and 2002. Breast (Edinburgh, Scotland) 2007, 16(4):344-351.

33. Lin NU, Claus E, Sohl J, Razzak AR, Arnaout A, Winer EP: Sites of distant recurrence and clinical outcomes in patients with metastatic triple-negative breast cancer: high incidence of central nervous system metastases. Cancer 2008, 113(10):2638-2645.

34. Kennecke H, Yerushalmi R, Woods R, Cheang MC, Voduc D, Speers CH, Nielsen TO, Gelmon K: Metastatic behavior of breast cancer subtypes. J Clin Oncol 2010, 28(20):3271-3277.

35. Elder EE, Kennedy CW, Gluch L, Carmalt HL, Janu NC, Joseph MG, Donellan MJ, Molland JG, Gillett DJ: Patterns of breast cancer relapse. Eur J Surg Oncol 2006, 32(9):922-927.

36. Mansell J, Monypenny IJ, Skene AI, Abram P, Carpenter R, Gattuso JM, Wilson CR, Angerson WJ, Doughty JC: Patterns and predictors of early recurrence in postmenopausal women with estrogen receptor-positive early breast cancer. Breast cancer research and treatment 2009, 117(1):91-98.

37. http://www.tumorregister-muenchen.de/facts/surv/surv_C50f_G.pdf

38. Manders K, van de Poll-Franse LV, Creemers GJ, Vreugdenhil G, van der Sangen MJ, Nieuwenhuijzen GA, Roumen RM, Voogd AC: Clinical management of women with metastatic breast cancer: a descriptive study according to age group. BMC Cancer 2006, 6:179.

39. Hess KR, Varadhachary GR, Taylor SH, Wei W, Raber MN, Lenzi R, Abbruzzese JL: Metastatic patterns in adenocarcinoma. Cancer 2006, 106(7):1624-1633.

40. Perez JE, Machiavelli M, Leone BA, Romero A, Rabinovich MG, Vallejo CT, Bianco A, Rodriguez R, Cuevas MA, Alvarez LA: Bone-only versus visceral-only metastatic pattern in breast cancer: analysis of 150 patients. A GOCS study. Grupo Oncologico Cooperativo del Sur. American journal of clinical oncology 1990, 13(4):294-298.

41. Giordano SH, Buzdar AU, Smith TL, Kau S-W, Yang Y, Hortobagyi GN: Is breast cancer survival improving? Trends in survival for patients with recurrent breast cancer diagnosed from 1974 through 2000. American Cancer Society 2003:44-52.

42. Lee YT: Breast carcinoma: pattern of metastasis at autopsy. J Surg Oncol 1983, 23(3):175-180.

43. Sanuki-Fujimoto N, Takeda A, Amemiya A, Ofuchi T, Ono M, Yamagami R, Hatayama J, Kunieda E, Shigematsu N: Pattern of tumor recurrence in initially nonmetastatic breast cancer patients: distribution and frequency of metastases at unusual sites. Cancer 2008, 113(4):677-682. 


\section{TABLES AND FIGURES}

Table 1. Characteristics of M0 patients with breast cancer according to period of initial diagnosis $(n=33,771)$

\begin{tabular}{|c|c|c|c|c|c|c|c|}
\hline \multirow[t]{3}{*}{ Characteristic } & \multicolumn{6}{|c|}{ Period of initial diagnosis } & \multirow[t]{3}{*}{ P-value } \\
\hline & \multicolumn{2}{|c|}{$\begin{array}{l}1978-1984 \\
(\mathrm{n}=4978)\end{array}$} & \multicolumn{2}{|c|}{$\begin{array}{l}1985-1994 \\
(n=10,201)\end{array}$} & \multicolumn{2}{|c|}{$\begin{array}{l}1995-2003^{* *} \\
(n=18,592)\end{array}$} & \\
\hline & $\mathrm{N}$ & $\%^{*}$ & $\mathrm{~N}$ & $\%^{*}$ & $\mathrm{~N}$ & $\%^{*}$ & \\
\hline $\begin{array}{l}\text { Median FU time after initial diagnosis } \\
\text { of patients alive or lost to FU (mo) }\end{array}$ & 148 & & 177 & & 80 & & $<0.0001$ \\
\hline Deceased (1 Oct. 2008) & 2893 & $(58)$ & 5123 & $(50)$ & 4571 & (25) & $<0.0001$ \\
\hline $\begin{array}{l}\text { M0 at diagnosis, metastasis in FU } \\
\text { M0 at diagnosis, metastasis within } 5\end{array}$ & 1785 & $(36)$ & 2999 & $(29)$ & 3399 & $(18)$ & $<0.0001$ \\
\hline years of $\mathrm{FU}$ & 798 & $(16)$ & 1159 & $(11)$ & 1952 & $(10)$ & $<0.0001$ \\
\hline \multicolumn{8}{|l|}{ Age (yrs) } \\
\hline$<50$ & 1909 & $(38)$ & 3522 & (35) & 4649 & (25) & \\
\hline $50-69$ & 2380 & $(48)$ & 4731 & $(46)$ & 9540 & (51) & \\
\hline $70+$ & 689 & (14) & 1948 & (19) & 4403 & (24) & $<0.0001$ \\
\hline \multicolumn{8}{|l|}{ pT } \\
\hline T1 & 978 & $(43)$ & 4155 & $(47)$ & 9358 & (55) & \\
\hline T2 & 958 & $(42)$ & 3524 & $(40)$ & 6224 & (37) & \\
\hline T3 & 202 & (9) & 436 & (5) & 723 & (4) & \\
\hline T4 & 149 & (6) & 693 & (8) & 747 & (4) & $<0.0001$ \\
\hline Unknown & 2691 & (54) & 1393 & (14) & 1545 & $(8)^{* *:}$ & \\
\hline \multicolumn{8}{|l|}{$\mathrm{pN}$} \\
\hline Negative & 1071 & $(48)$ & 4413 & (52) & 9649 & (59) & \\
\hline Positive & 1142 & (52) & 4114 & $(48)$ & 6682 & (41) & $<0.0001$ \\
\hline Unknown & 2765 & $(56)$ & 1674 & $(16)$ & 2261 & (12) & \\
\hline \multicolumn{8}{|l|}{ Histological type } \\
\hline Ductal & 3533 & $(82)$ & 7445 & $(80)$ & 13970 & (78) & \\
\hline Lobular/Mixed & 419 & (10) & 1486 & $(16)$ & 3678 & (21) & \\
\hline Other/n.o.s. & 363 & (8) & 346 & (4) & 276 & (1) & $<0.0001$ \\
\hline Unknown & 663 & (13) & 924 & (9) & 668 & (4) & \\
\hline \multicolumn{8}{|l|}{ Grade } \\
\hline 1 & - & - & 485 & (6) & 1902 & (11) & \\
\hline 2 & - & - & 4440 & $(58)$ & 9311 & (53) & \\
\hline $3+4$ & - & - & 2748 & (36) & 6206 & (36) & $<0.0001$ \\
\hline Unknown & - & - & 2528 & (25) & 1173 & (6) & \\
\hline \multicolumn{8}{|l|}{ Receptor status (ER or PR) } \\
\hline Positive & - & - & 4336 & (79) & 13,120 & (84) & \\
\hline Negative & - & - & 1140 & (21) & 2577 & (16) & $<0.0001$ \\
\hline Unknown & - & - & 4725 & (46) & 2900 & (16) & \\
\hline \multicolumn{8}{|l|}{ Initial surgery } \\
\hline Lumpectomy & 49 & (2) & 2660 & (39) & 10,835 & (65) & \\
\hline Mastectomy & 1920 & (98) & 4248 & (61) & 5841 & (35) & $<0.0001$ \\
\hline Unknown/ Other ${ }^{* * * *}$ & 3009 & $(60)$ & 3293 & (32) & 1916 & (10) & \\
\hline
\end{tabular}




\begin{tabular}{|c|c|c|c|c|c|c|c|}
\hline Initial radiotherapy & 2729 & (59) & 4534 & $(44)$ & 10910 & (59) & $<0.0001$ \\
\hline \multicolumn{8}{|l|}{ Resection margins } \\
\hline Negative & - & - & 2923 & (29) & 12,833 & (69) & \\
\hline Positive & - & - & 152 & (1) & 590 & (3) & \\
\hline Unknown & - & - & 7126 & (70) & 5169 & (28) & $<0.0001$ \\
\hline \multicolumn{8}{|c|}{ Initial systemic treatment } \\
\hline Chemotherapy & 673 & (13) & 1959 & (19) & 4345 & (23) & \\
\hline Hormonal therapy & 375 & (8) & 2324 & (23) & 6271 & (34) & \\
\hline Both & 59 & (1) & 217 & (2) & 2394 & (13) & \\
\hline No & 3871 & (78) & 5701 & (56) & 5582 & (30) & $<0.0001$ \\
\hline
\end{tabular}

FU=follow-up n.o.s. = not otherwise specified, ER=ostrogen receptor, PR=progesteron receptor * percentage of sub-categories related to the sum of each item with available data; missing values not taken into account.

** The population based cohort.

*** pT missing in $4 \%$ out of $8 \%$ because of neo-adjuvant systemic therapy

**** no differentiation for surgical method in the 1970's and early 1980's. 'Other' is for example surgery following neo-adjuvant systemic therapy 
Table 2. Characteristics of M0 breast cancer patients with first metastasis within 5 years of initial diagnosis, according to period of initial diagnosis $(n=5490)$

\begin{tabular}{|c|c|c|c|c|c|c|c|}
\hline \multirow[t]{3}{*}{ Characteristic } & \multicolumn{6}{|c|}{ Period of initial diagnosis } & \multirow[t]{3}{*}{ P-value } \\
\hline & \multicolumn{2}{|c|}{$\begin{array}{c}1978-1984 \\
(n=1214)\end{array}$} & \multicolumn{2}{|c|}{$\begin{array}{c}1985-1994 \\
(n=1677)\end{array}$} & \multicolumn{2}{|c|}{$\begin{array}{c}1995-2003 \\
(n=2599)\end{array}$} & \\
\hline & $\mathrm{N}$ & $\%$ & $\mathrm{~N}$ & $\%$ & $\mathrm{~N}$ & $\%$ & \\
\hline Metastasis within 2.5 years & 791 & (65) & 999 & $(60)$ & 1449 & (56) & $<0.0001$ \\
\hline $\begin{array}{l}\text { Deceased within } 5 \text { years of first } \\
\text { metastasis }\end{array}$ & 1031 & (85) & 1484 & (88) & 2464 & (95) & $<0.0001$ \\
\hline $\begin{array}{l}\text { Median FU time after initial } \\
\text { diagnosis of patients alive or lost } \\
\text { to FU (mo) }\end{array}$ & 29 & & 11 & & 50 & & $<0.0001$ \\
\hline $\begin{array}{l}\text { Multiple synchronous } \\
\text { Multiple metachronous }\end{array}$ & $\begin{array}{l}603 \\
399\end{array}$ & $\begin{array}{l}(50) \\
(66)\end{array}$ & $\begin{array}{l}862 \\
637\end{array}$ & $\begin{array}{l}(51) \\
(74)\end{array}$ & $\begin{array}{l}1592 \\
1300\end{array}$ & $\begin{array}{l}(61) \\
(82)\end{array}$ & $\begin{array}{l}<0.0001 \\
<0.0001\end{array}$ \\
\hline $\begin{array}{l}\text { Metastatic sites at first } \\
\text { progression/ all metastases } \\
\text { during follow-up* }\end{array}$ & & & & & & & \\
\hline $\begin{array}{l}\text { Bone } \\
\text { Lung } \\
\text { Liver } \\
\text { CNS } \\
\text { Skin } \\
\text { Distant lymph node } \\
\text { Other } \\
\text { Total } \\
\text { Mean number of metastases per } \\
\text { patient }\end{array}$ & $\begin{array}{r}719(60) / \\
286(24) / \\
168(14) / \\
55(5) / \\
92(8) / \\
74(6) / \\
164(14) / \\
1558 / \\
1.28 /\end{array}$ & $\begin{array}{r}838(69) \\
376(31) \\
286(24) \\
123(10) \\
149(12) \\
104(9) \\
287(24) \\
2163 \\
1.78\end{array}$ & $\begin{array}{r}881(53) / \\
372(22) / \\
266(16) / \\
81(5) / \\
109(7) / \\
189(11) / \\
219(13) / \\
2117 / \\
1.26 /\end{array}$ & $\begin{array}{r}1047(62) \\
533(32) \\
484(29) \\
232(14) \\
177(11) \\
273(16) \\
427(25) \\
3173\end{array}$ & $\begin{array}{r}980(38) \text { / } \\
514(20) \text { / } \\
587(23) / \\
265(10) \text { / } \\
171(7) \text { / } \\
284(11) \text { / } \\
630(24) \text { / } \\
3431 \text { / } \\
1.32 \text { / }\end{array}$ & $\begin{array}{l}1226(47) \\
783(29) \\
961(35) \\
630(22) \\
290(11) \\
413(15) \\
1267(51) \\
5579 \\
2.14\end{array}$ & \\
\hline $\begin{array}{l}\text { Age (yrs) } \\
\quad<50 \\
50-69 \\
70+\end{array}$ & $\begin{array}{l}506 \\
576 \\
132\end{array}$ & $\begin{array}{l}(42) \\
(47) \\
(11)\end{array}$ & $\begin{array}{l}653 \\
794 \\
230\end{array}$ & $\begin{array}{l}(39) \\
(47) \\
(14)\end{array}$ & $\begin{array}{r}723 \\
1245 \\
631\end{array}$ & $\begin{array}{l}(28) \\
(48) \\
(24)\end{array}$ & $=0.0001$ \\
\hline $\begin{array}{l}\mathrm{pT} \\
\text { T1 } \\
\text { T2 } \\
\text { T3 } \\
\text { T4 } \\
\text { Unknown (\%) }\end{array}$ & $\begin{array}{r}132 \\
234 \\
72 \\
40 \\
736\end{array}$ & $\begin{array}{r}(28) \\
(49) \\
(15) \\
(8) \\
(61)\end{array}$ & $\begin{array}{l}411 \\
688 \\
122 \\
184 \\
272\end{array}$ & $\begin{array}{r}(29) \\
(49) \\
(9) \\
(13) \\
(16)\end{array}$ & $\begin{array}{r}612 \\
1118 \\
213 \\
234 \\
422\end{array}$ & $\begin{array}{l}(28) \\
(51) \\
(10) \\
(11) \\
(16)\end{array}$ & 0.0004 \\
\hline $\begin{array}{l}\mathrm{pN} \\
\text { Negative } \\
\text { Positive } \\
\text { Unknown (\%) }\end{array}$ & $\begin{array}{l}137 \\
320 \\
757\end{array}$ & $\begin{array}{l}(30) \\
(70) \\
(62)\end{array}$ & $\begin{array}{l}433 \\
949 \\
295\end{array}$ & $\begin{array}{l}(31) \\
(69) \\
(18)\end{array}$ & $\begin{array}{r}650 \\
1463 \\
486\end{array}$ & $\begin{array}{l}(31) \\
(69) \\
(19)\end{array}$ & 0.9 \\
\hline $\begin{array}{l}\text { Receptor status (ER or PR) } \\
\text { Negative } \\
\text { Positive } \\
\text { Unknown (\%) }\end{array}$ & $\begin{array}{l}- \\
- \\
-\end{array}$ & $\begin{array}{l}- \\
- \\
-\end{array}$ & $\begin{array}{l}228 \\
562 \\
887\end{array}$ & $\begin{array}{l}(29) \\
(71) \\
(53)\end{array}$ & $\begin{array}{r}605 \\
1441 \\
553\end{array}$ & $\begin{array}{l}(30) \\
(70) \\
(21)\end{array}$ & 0.7 \\
\hline
\end{tabular}


$\mathrm{FU}=$ follow-up $\mathrm{M} 0=$ no metastases at diagnose $\mathrm{CNS}=$ central nervous system $\mathrm{ER}=\mathrm{ostrogen}$ receptor, $\mathrm{PR}=$ progesteron receptor

* Since one patient can have more than one site of metastasis, percentages are more than $100 \%$ 
Table 3. Determinants of time to first metastasis in M0 breast cancer patients, within 5 years of initial diagnosis.

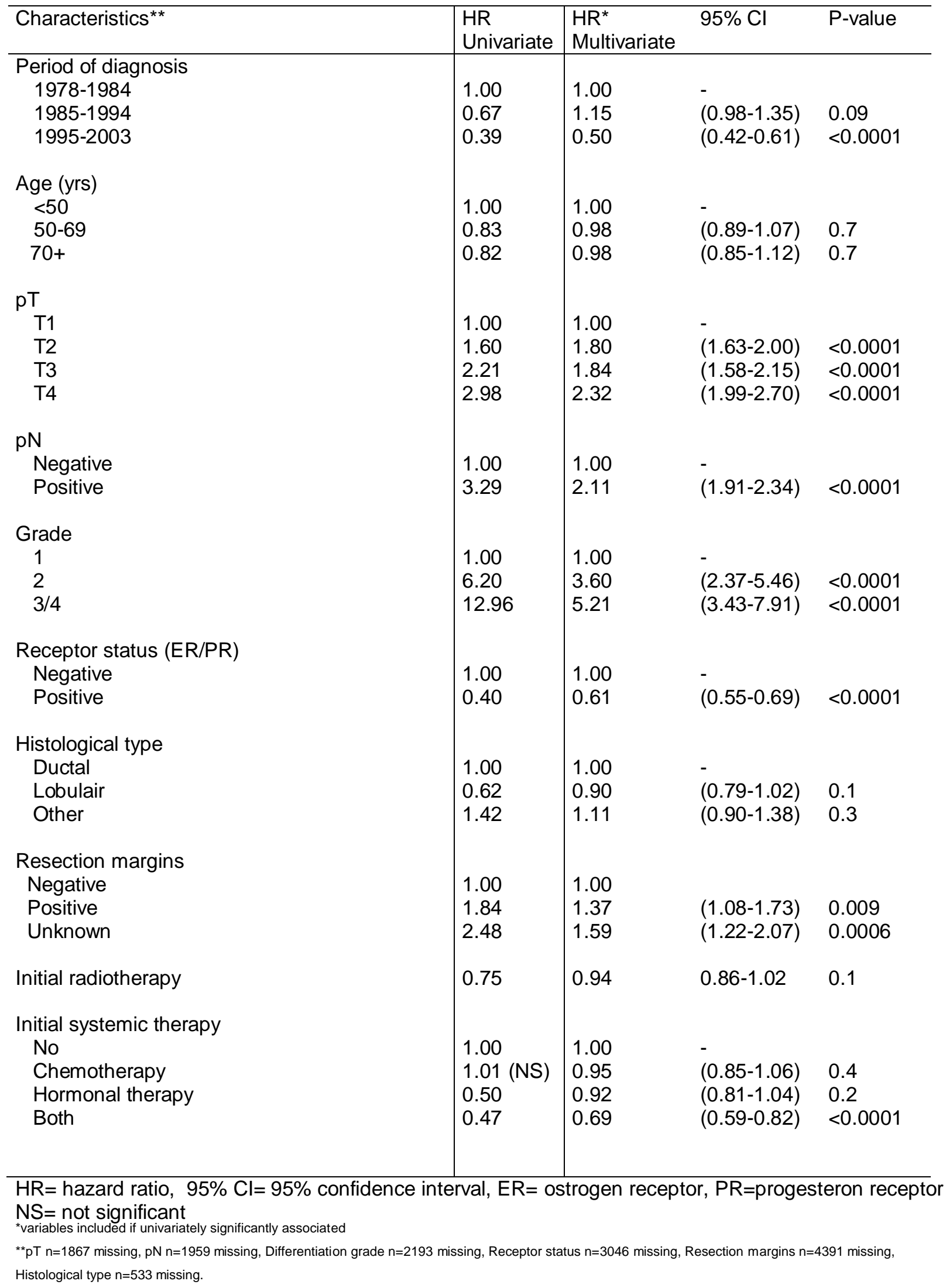


Table 4. Determinants of survival after first metastasis in $\mathrm{M} 0$ breast cancer patients with metastases within 5 years during follow-up

\begin{tabular}{|c|c|c|c|c|c|c|c|}
\hline Characteristics $^{* \star *}$ & \begin{tabular}{|l|}
$\mathrm{HR}$ \\
Univariate
\end{tabular} & $\begin{array}{l}\mathrm{HR}^{\star * *} \\
\text { Multi } \\
\text { variate }\end{array}$ & $95 \% \mathrm{Cl}$ & P-value & $\begin{array}{l}\mathrm{HR} \\
\text { Multi } \\
\text { variate } \\
\end{array}$ & $95 \% \mathrm{Cl}$ & P-value \\
\hline $\begin{array}{l}\text { Period of diagnosis } \\
1978-1984 \\
1985-1994 \\
1995-2003\end{array}$ & $\begin{array}{l}1.00 \\
1.31 \\
1.38\end{array}$ & $\begin{array}{l}1.00 \\
1.24 \\
1.21\end{array}$ & $\begin{array}{l}- \\
(1.08- \\
1.43) \\
(1.04- \\
1.40)\end{array}$ & $\begin{array}{l}0.003 \\
0.02\end{array}$ & $\begin{array}{l}1.00 \\
1.20 \\
1.08\end{array}$ & $\begin{array}{l}- \\
(1.04-1.38) \\
(0.93-1.26)\end{array}$ & $\begin{array}{l}<0.01 \\
0.3\end{array}$ \\
\hline $\begin{array}{l}\text { Age (yrs) } \\
<50 \\
50-69 \\
70+\end{array}$ & $\begin{array}{l}1.00 \\
1.13 \\
1.58\end{array}$ & $\begin{array}{l}1.00 \\
1.12 \\
1.51\end{array}$ & $\begin{array}{l}- \\
(1.04- \\
1.22) \\
(1.34- \\
1.69)\end{array}$ & $\begin{array}{l}0.004 \\
<0.0001\end{array}$ & $\begin{array}{l}1.00 \\
1.14 \\
1.57\end{array}$ & $\begin{array}{l}- \\
(1.05-1.24) \\
(1.40-1.75)\end{array}$ & $\begin{array}{l}0.001 \\
<0.0001\end{array}$ \\
\hline $\begin{array}{l}\mathrm{pT} \\
\text { T1 } \\
\text { T2 } \\
\text { T3 } \\
\text { T4 }\end{array}$ & $\begin{array}{l}1.00 \\
1.20 \\
1.26 \\
1.46\end{array}$ & $\begin{array}{l}1.00 \\
1.14 \\
1.19 \\
1.23\end{array}$ & $\begin{array}{l}- \\
(1.05- \\
1.25) \\
(1.04- \\
1.37) \\
(1.07- \\
1.41)\end{array}$ & $\begin{array}{l}0.003 \\
0.01 \\
0.003\end{array}$ & $\begin{array}{l}1.00 \\
1.14 \\
1.19 \\
1.22\end{array}$ & $\begin{array}{l}- \\
(1.04-1.24) \\
(1.04-1.36) \\
(1.06-1.40)\end{array}$ & $\begin{array}{l}0.004 \\
0.01 \\
0.004\end{array}$ \\
\hline $\begin{array}{l}\mathrm{pN} \\
\text { Negative } \\
\text { Positive }\end{array}$ & $\begin{array}{l}1.00 \\
1.29\end{array}$ & $\begin{array}{l}1.00 \\
1.21\end{array}$ & $\begin{array}{l}- \\
(1.12- \\
1.32)\end{array}$ & $<0.0001$ & $\begin{array}{l}1.00 \\
1.22\end{array}$ & $\begin{array}{l}- \\
(1.13-1.33)\end{array}$ & $<0.0001$ \\
\hline $\begin{array}{l}\text { Grade } \\
\quad 1 \\
2 \\
3 / 4\end{array}$ & $\begin{array}{l}1.00 \\
1.70 \\
2.39\end{array}$ & $\begin{array}{l}1.00 \\
1.70 \\
2.17\end{array}$ & $\begin{array}{l}- \\
(1.21- \\
2.40) \\
(1.54- \\
3.06)\end{array}$ & $\begin{array}{l}0.002 \\
<0.0001\end{array}$ & $\begin{array}{l}1.00 \\
1.64 \\
2.05\end{array}$ & $\begin{array}{l}- \\
(1.17-2.31) \\
(1.46-2.89)\end{array}$ & $\begin{array}{l}0.005 \\
<0.0001\end{array}$ \\
\hline $\begin{array}{l}\text { Receptor status (ER/PR) } \\
\text { Negative } \\
\text { Positive }\end{array}$ & $\begin{array}{l}1.00 \\
0.58\end{array}$ & $\begin{array}{l}1.00 \\
0.62\end{array}$ & $\begin{array}{l}- \\
(0.56- \\
0.69)\end{array}$ & $<0.0001$ & $\begin{array}{l}1.00 \\
0.65\end{array}$ & $\begin{array}{l}- \\
(0.59-0.72)\end{array}$ & $<0.0001$ \\
\hline $\begin{array}{l}\text { Histological type } \\
\text { Ductal } \\
\text { Lobular } \\
\text { Other }\end{array}$ & $\begin{array}{l}1.00 \\
0.93 \text { (NS) } \\
1.03 \text { (NS) }\end{array}$ & $\begin{array}{l}- \\
- \\
-\end{array}$ & & & $\begin{array}{l}- \\
- \\
-\end{array}$ & & \\
\hline $\begin{array}{l}\text { Time to first metastasis }{ }^{\star \star \star *} \\
\text { Site(s) of Metastases } \\
\text { Bone alone } \\
\text { Liver alone } \\
\text { Lung alone } \\
\text { CNS alone } \\
\text { Skin alone } \\
\text { Distant lymph nodes alone } \\
\text { Liver, Bone } \\
\text { Lung, Bone } \\
\text { Bone, Liver, Lung }\end{array}$ & $\begin{array}{l}1.00 \\
1.39 \\
1.09(\mathrm{NS}) \\
3.16 \\
1.01(\mathrm{NS}) \\
1.13(\mathrm{NS}) \\
1.38 \\
1.28 \\
1.66\end{array}$ & $\begin{array}{l}- \\
- \\
- \\
- \\
- \\
- \\
- \\
- \\
-\end{array}$ & $\begin{array}{l}(0.91- \\
0.96)\end{array}$ & $<0.0001$ & $\begin{array}{l}1.00 \\
1.38 \\
1.20 \\
2.81 \\
0.97 \\
0.94 \\
1.50 \\
1.18 \\
\\
\\
1.67\end{array}$ & $\begin{array}{l}- \\
(1.15-1.67) \\
(0.97-1.47) \\
(2.20-3.57) \\
(0.71-1.33) \\
(0.72-1.23) \\
(1.25-1.79) \\
(0.92-1.50) \\
(1.33-2.10)\end{array}$ & $\begin{array}{l}<0.0008 \\
0.1 \\
<0.0001 \\
0.9 \\
0.6 \\
<0.0001 \\
0.2 \\
<0.0001\end{array}$ \\
\hline
\end{tabular}


$\mathrm{HR}=$ hazard ratio, $95 \% \mathrm{Cl}=95 \%$ confidence interval, $\mathrm{ER}=$ ostrogen receptor, $\mathrm{PR}=$ progesteron receptor $\mathrm{NS}=$ not significant, $\mathrm{CNS}=$ central nervous system

*variables included if they were univariate significantly associated

** pT $n=1334$ missing, pN n=1413 missing, grade $n=1720$ missing, Receptor status $n=2379$ missing, site of metastases 'Other' $n=2646$.

*** HR when site of metastases is excluded

$\star * * *$ in years

Figure 1. 5-year overall survival of M0 breast cancer patients diagnosed between 1978 and $2003(n=33771)$

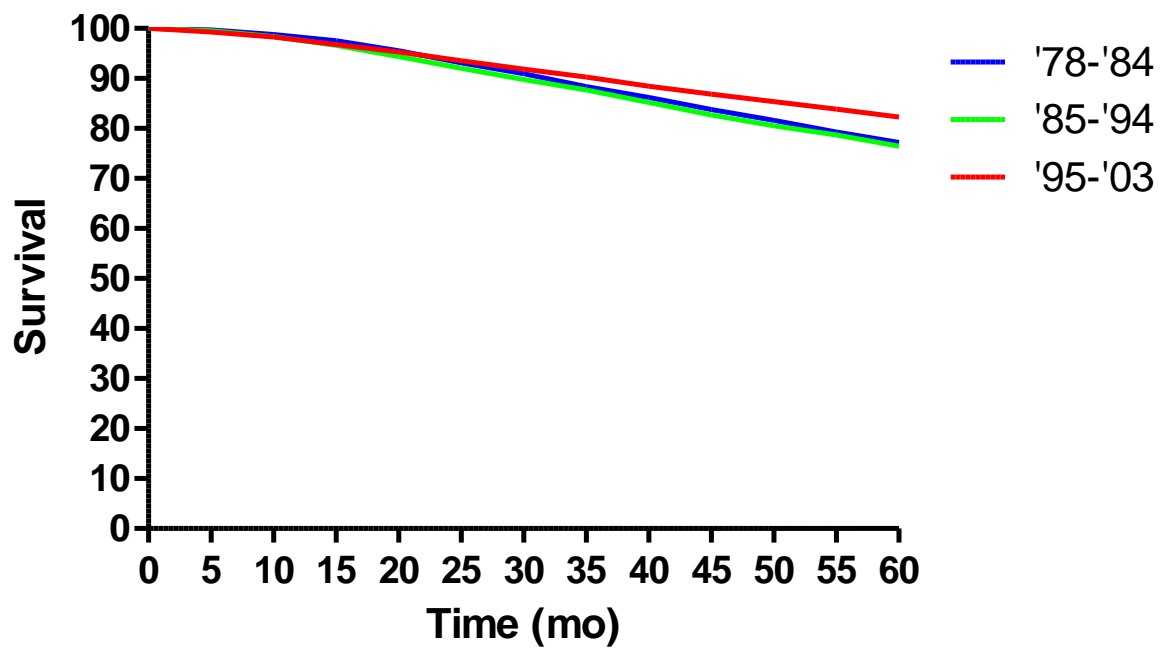

Figure 2a. 5-year actuarial rate of occurrence of first metastases in M0 breast cancer patients according to period of diagnosis of initial tumour

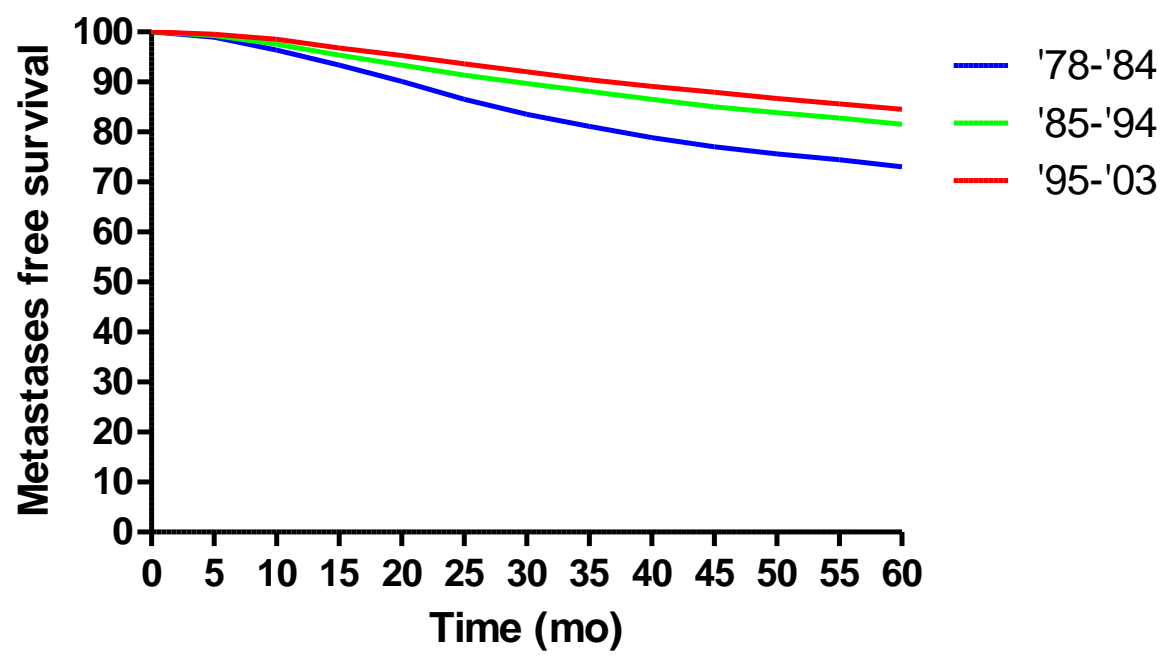


Figure 2b. Survival following first metastasis in M0 breast cancer patients who developed metastasis within 5 years of diagnosis according to period of diagnosis of initial tumour



Figure 3. Time from diagnosis of primary tumour to first metastasis at the most common single sites and combinations of sites in M0 breast cancer patients with metastases within 5 years of diagnosis

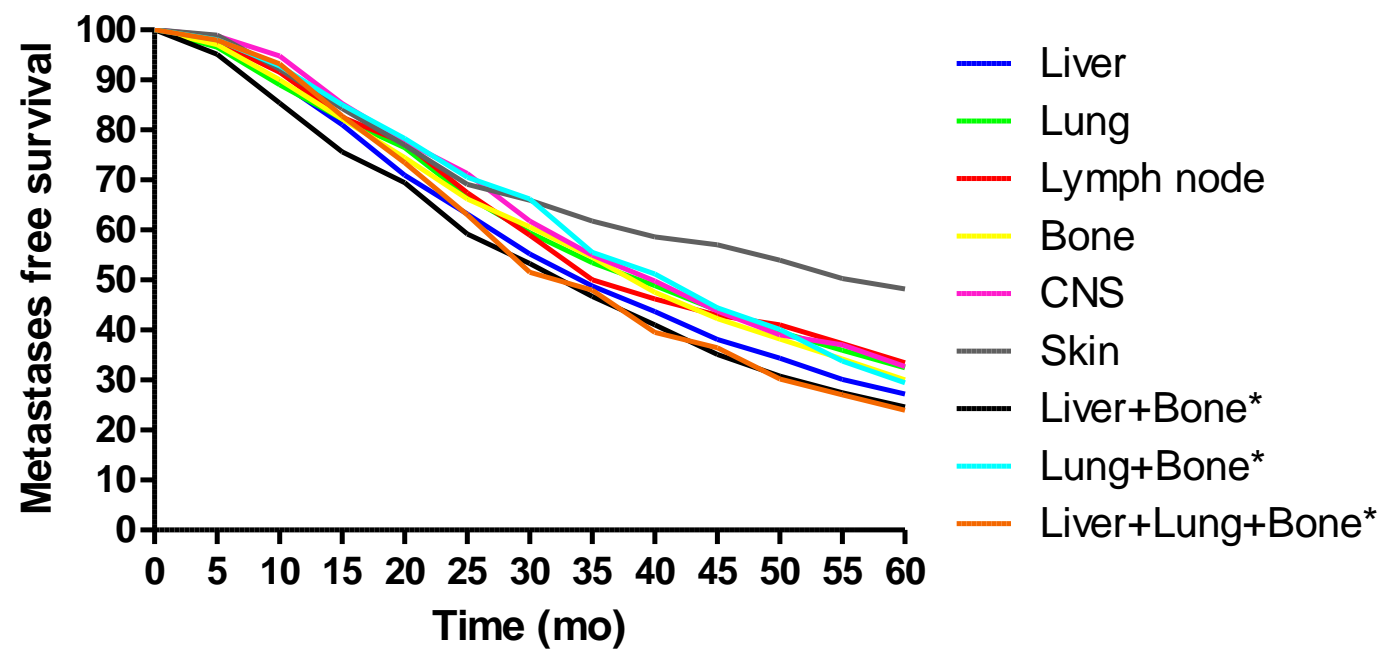

CNS $=$ central nervous system

*Independent of sequence of detection per site, synchronous or metachronous, no additional metastases at other sites. 
Figure 4. 5-Year survival after first metastasis in most common single sites and combinations of sites of metastases in $\mathrm{M} 0$ breast cancer patients with metastases within 5 years of diagnosis

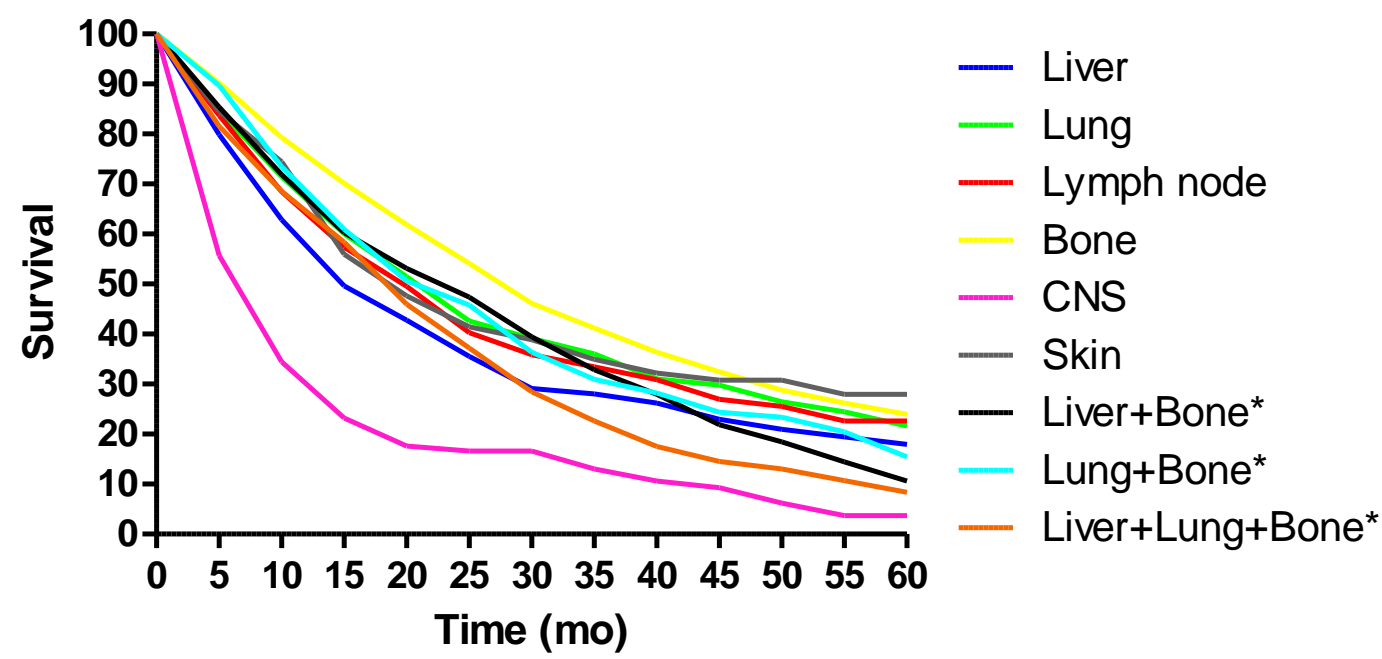

$\mathrm{CNS}=$ central nervous system

*Independent of sequence of detection per site, synchronous or metachronous, no additional metastases at other sites. 